ISSN 0258-7122

Bangladesh J. Agril. Res. 39(4): 693-707, December 2014

\title{
EFFECT OF SEED PRIMING ON MAIZE (Zea mays L.) SEEDLING EMERGENCE UNDER DIFFERENT SOWING DATES
}

\author{
M. M. RAHMAN ${ }^{1}$, K. U. AHAMMAD ${ }^{2}$ AND M. AHMED ${ }^{3}$
}

\begin{abstract}
The experiment was carried out at the research field of Regional Agricultural Research Station, Jessore during 2009-10 and 2010-2011 to find out the effect of priming and ambient temperatures due to different sowing dates on emergence of maize seedlings. The experiment consisted of two priming methods viz., i) Priming, ii) Non-priming, and ten sowing dates viz., i) 15 November, ii) 30 November, iii) 15 December iv) 30 December v) 14 January vi) 29 January vii) 13 February viii) 28 February, ix) 15 March, and x) 30 March. The experiment was laid out in a randomized complete block design with three replications. Results showed that germination percentage, germination index, mean germination time and dry matter/plant were influenced significantly by priming. The highest germination percentage, germination index, dry matter/plant and lowest mean germination time were recorded from primed seed sown in March followed by February and November sowings but those were very poor in December and January sowings. So, primed seeds should be sown in November and February for better stand establishment of maize.
\end{abstract}

Keywords: Seed priming, maize (Zea mays L.), sowing date, seedling emergence.

\section{Introduction}

Maize (Zea mays L.) is one of the most important food grains of the world. In Bangladesh, maize ranks third of total acreage after rice and wheat but ranks first in respect of average yield which is $5.30 \mathrm{t} /$ ha for Maize (BBS, 2010). Maize is the most popular and palatable feed for all kinds of livestock and poultry birds all over the world (Hossain and Shahjahan, 2007). Good seedling establishment is an important prerequisite for successful crop production (Harris et al., 1999) and this is particularly true for crops, such as maize which do not have the capacity to adjust to sub-optimal stand by tillering (Finch Savage et al., 2004). Constraints to good establishment of crops include low seed quality, lack of soil moisture, temperature extremities, soil salinity, poor seed bed preparation, weed competition, extreme disease pressure, etc. (Townend et al., 1996). When seeds are sown, they have to absorb water from the soil which take a long time before they germinate. If this time could be reduced by soaking the seeds before they are sown, germination happens more quickly resulting in a healthier crop. Seed

\footnotetext{
${ }^{1 \& 3}$ Professor, Department of Agronomy, Bangladesh Agricultural University (BAU), Mymansingh, ${ }^{2}$ Senior Scientific Officer, RARS, Bangladesh Agricultural Research Institute (BARI), Jessore, Bangladesh.
} 
priming can be a simple solution towards expected stand establishment (Harris et $a l ., 2001)$. Seed priming is a process in which seeds are imbibed in water or osmotic solutions followed by drying before radicle emergence (McDonald, 2000). Seed priming has been reported to improve germination, reduce seedling germination time, and improve stand establishment, increase emergence, earlier flowering, earlier maturing and higher grain yield (Harris et al., 1999). Hydropriming involves allowing seeds to absorb sufficient water to initiate metabolic process but insufficient water to allow completion of germination. When seeds are imbibed, the lag period before radicle emergence is considerably reduced and improved the rate and uniformity of germination. Singh (1995) and Shivankar et al. (2003) observed that hydropriming practically ensured rapid and uniform germination accompanied with low abnormal seedling percentage. Hydropriming of maize seeds showed rapid seedling emergence and improved field stand (Nagar et al., 1998).

Pre-sowing seed invigoration treatments have beneficial effect on field emergence, crop stand and seedling growth of Maize under low and sub-optimal temperatures (Rashid et al., 2002). Emergence performance of maize seeds varies with sowing dates due to variation in ambient temperature. Farooq et al. (2008) and Basu et al. (2005) found that primed seed sown at higher temperature showed higher emergence performance and dry matter compared to low temperature. Medany et al. (2007) stated that optimum temperature for maize growing is between 25 and $30^{\circ} \mathrm{C}$. Maize being a crop of tropical origin requires optimum temperature of $25^{\circ} \mathrm{C}$ for proper growth and development (Basu, 1999) and the prevailing sub-optimum temperatures affect the field emergence and early vegetative phase of the crop.

Maize can be produced successfully by priming seed at low moisture content of soil after harvesting transplant Aman rice. However, the priming technique of this crop is not well established in Bangladesh. Although quite a good number of works have been done on seed priming of Maize in abroad but under Bangladesh condition, such works are a few. Therefore, the present experiment was undertaken to find out the effect of priming and ambient temperature due to different sowing dates on emergence of Maize seedling.

\section{Materials and Method}

The experiment was conducted in two consecutive years at the research field of Regional Agricultural Research Station, Jessore during 2009-10 and 2010-2011. The experimental site belongs to the High Ganges River Floodplain soil. The soil is characterized by sandy loam to silty clay loam with $\mathrm{pH}$ value of 7.0-8.0. Organic matter, total $\mathrm{N}$, and $\mathrm{K}$ of the soil were $1.68 \%, 0.087 \%$, and 0.20 
meq/100g soil, and P, S, Zn, and B were 5.09, 20.20, 2.80, and $0.32 \mu \mathrm{g} / \mathrm{g}$ soil. The maximum and minimum average temperatures were 35 and $16{ }^{\circ} \mathrm{C}$ in the month of April and December, during 2009-10 and 2010-11. The total rainfalls were 1222.60 and $827.70 \mathrm{~mm}$ in $2009-10$ and $2010-11$. There was no rainfall in the month of November to January during 2009-10 to 2010-11. Monthly average relative humidity ranged from 88.62 to $95.87 \%$ in $2009-10$ and 90.27 to $95.63 \%$ in 2010-11. The treatments of the experiment consisted of two priming methods viz., i) Hydropriming ii) Non priming, and ten sowing dates viz., i) 15 November, ii) 30 November, iii) 15 December, iv) 30 December, v) 14 January, vi) 29 January, vii) 13 February, viii) 28 February, ix) 15 March, and x) 30 March. The experiment was laid out in a randomized complete block design with three replications. Maize (var. BARI Hybrid Maize 5) seeds were taken in plastic bowls and submerged with distilled water for 18 hours. Then seeds were washed under tap water for several times and surface dried for two hours under shade. Seeds were sown in well prepared plots at $2 \mathrm{~cm}$ depth in soil maintaining $75 \mathrm{~cm}$ $\times 20 \mathrm{~cm}$ spacing. Fertilizers were applied at the rate of 230-48-90-43-3.5-1 kg/ha in the form of N-P-K-S-Zn, and B (BARI, 2006). One-third of Urea and all other fertilizers were applied as basal during final land preparation. One hand weeding was done at 20 days after sowing (DAS) for minimizing weed competition and one irrigation was applied after weeding. The experiment continued up to 30 days. Data on different parameters were recorded following the procedures as below-

Germination percentage: The seedlings were counted daily until complete emergence. Germination was calculated in percentage using the following formula:

$\%$ Germination $=\frac{\text { Number of seeds germinated }}{\text { Number of seeds sown }} \times 100$

Germination index: The germination index (GI) was calculated by following formula (AOSA, 1983):

$\mathrm{GI}=\frac{\text { Number of germinated seeds }}{\text { Day s of first count }}+-----+\frac{\text { Number of germinated seeds }}{\text { Day sof final count }}$

Mean germination time: The mean germination time (days) was calculated according to the following formula (Scott et al., 1984):

$\operatorname{MGT}($ days $)=\frac{\Sigma \mathrm{TiNi}}{\mathrm{S}}$

Where, $\mathrm{Ti}=$ Number of days after beginning of experiment

$\mathrm{Ni}=$ Number of seeds germination on day $\mathrm{i}$

$\mathrm{S}=$ Total number of seeds germination 
Dry matter/plant: Plant dry matter at 30 DAS (days after sowing) was recorded after drying plant samples in an oven at $70{ }^{\circ} \mathrm{C}$ for 72 hours.

Data were subjected to statistical analysis using ANOVA technique through computer based statistical package programme MSTATC. Square root transformations of percentage data were done before the analysis (Gomez and Gomez, 1984). Mean comparison was done by Duncun's Multiple Range Test (DMRT) at 5\% level.

\section{Results}

\section{Germination percentage}

Germination of maize seed was influenced significantly by priming methods and dates of sowing in 2009-10 and 2010-11. Primed seeds showed higher germination $(83 \%)$ than that of $(75 \%)$ non-primed seeds (Fig. 1). In both the years, germination was highest at 30 March sowing followed by that at 15 March, 15 November, 30 November sowings and it was the lowest on 30 December. The highest (82\%) germination was obtained from 30 March, which was statistically identical with 15 March $(81 \%), 15$ November $(81 \%)$ and the lowest (77\%) from 30 December sowing (Fig. 2).

Germination of maize was influenced significantly by the interaction of priming and sowing date in 2009-10 and 2010-11 (Table 1). The highest germination was recorded when primed seeds were sown on 30 March followed by 15 March, 15 November and the lowest germination was noticed from nonprimed seed sown on 30 December.

\section{Germination index}

Germination index of maize seed varied significantly due to priming and dates of sowing in both the years (Fig. 3). Average germination index was higher (12.29) from primed seeds than the non-primed seeds (9.74). In both the years, germination index from seed sown on 30 March was the highest followed by sowing on 15 March, 15 November and the lowest from 30 December sowing. Average germination index of both the years was highest (14.31) from 30 March sowing followed by 15 March (13.56), 15 November (13.20) and the lowest (6.97) from sowing on 30 December (Figure 4).

Germination index of maize was influenced significantly by the interaction of priming and sowing date in both the years (Table 1). The highest (15.68) mean germination index was obtained from primed seeds when it was sown on 30 
March followed by sowing on 15 March (15.41), 15 November (14.80) and the lowest from non-primed seeds sown on 30 December (6.15).

\section{Mean germination time}

The mean germination time (MGT) varied significantly due to priming and dates of sowing in both the years (Fig. 5). Average mean germination time was lower (7.39 day) in primed seeds than that of non- primed seeds (8.48 day). MGT from 30 March sowing was the lowest followed by sowing on 15 March, 28 February, 15 November and the highest from 30 December. Average MGT of both the trials was the lowest (5.18 day) from 30 March sowing followed by sowing on 15 March (5.98 day), 28 February (6.09 day), 15 November (6.34 day) and the highest (11.69 day) from 30 December sowing (Fig. 6).

MGT was influenced significantly by the interaction of seed priming and sowing date in both the years (Table 1). The lowest MGT was obtained from primed seeds when sown on 30 March followed by 15 March, 28 February, 15 November and it was the highest from non-primed seeds sown on 30 December. Average MGT of both the years was the lowest (4.47 day) from hydroprimed seeds sown on 30 March followed by seeds sown on 15 March (5.39 day), 28 February (5.54 day), 15 November (5.76 day) and the highest (12.15 day) from non-primed seeds sown on 30 December.

\section{Dry matter}

Dry matter (DM) per plant of maize showed significant variation due to priming and dates of sowing (Fig. 7). Average dry matter of both the years was higher $(4.89 \mathrm{~g})$ from primed seed than that of non-priming (3.88 g). DM/plant of Maize sown on 30 March was the highest followed by that sown on 15 March, 15 November, 28 February and the lowest from 30 December. Average dry matter/plant was the highest $(9.78 \mathrm{~g})$ from 30 March sowing followed by 15 March (9.24 g), 15 November $(7.95 \mathrm{~g})$ and the lowest $(0.66 \mathrm{~g})$ from 30 December, which was statistically identical with 30 December $(0.67 \mathrm{~g})$ and 15 December (0.70 g) (Fig. 8).

$\mathrm{DM} /$ plant of maize showed significant variation due to interaction of priming and sowing date in both the years (Table 1). The highest average DM (10.80 g) was obtained from primed seeds when sown on 30 March followed by 15 March $(10.18 \mathrm{~g}), 15$ November $(8.64 \mathrm{~g})$ and the lowest from non-primed seeds sown on 30 December $(0.62 \mathrm{~g})$. 


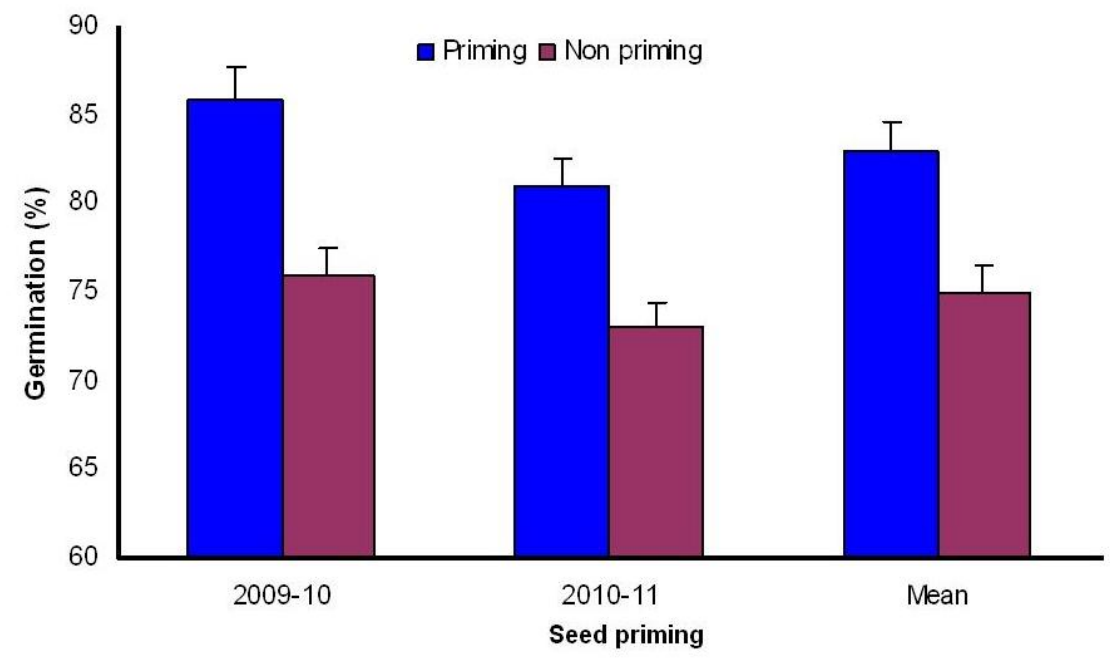

Fig. 1. Effect of priming on the germination percentage of maize seed in 2009-10 and 2010-11 (Vertical bars represent standard error of means).

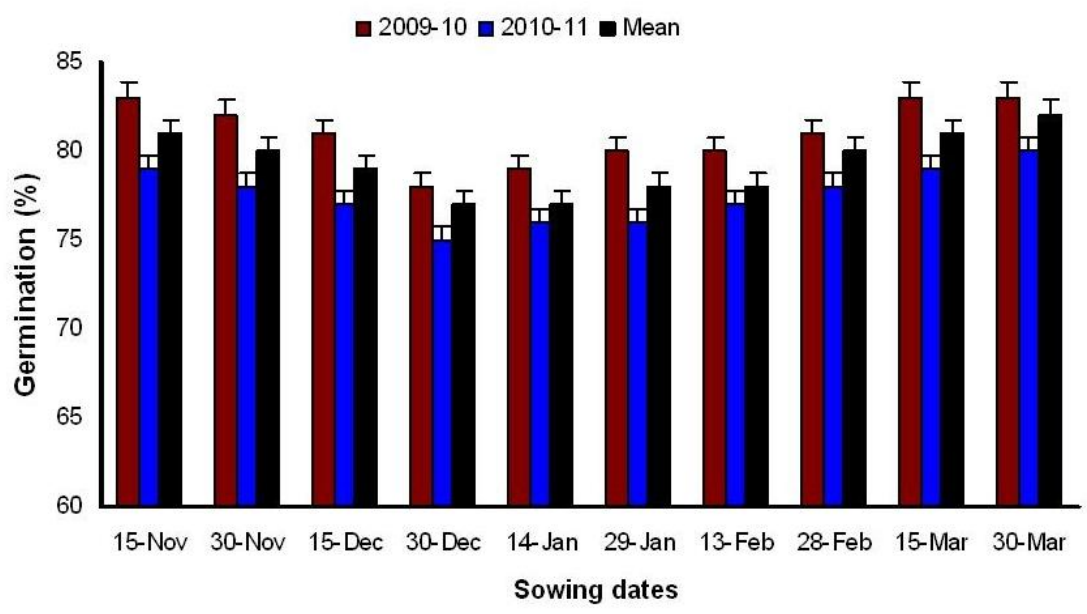

Fig. 2. Effect of sowing dates on the germination percentage of maize seed in 2009 10 and 2010-11(Vertical bars represent standard error of means). 


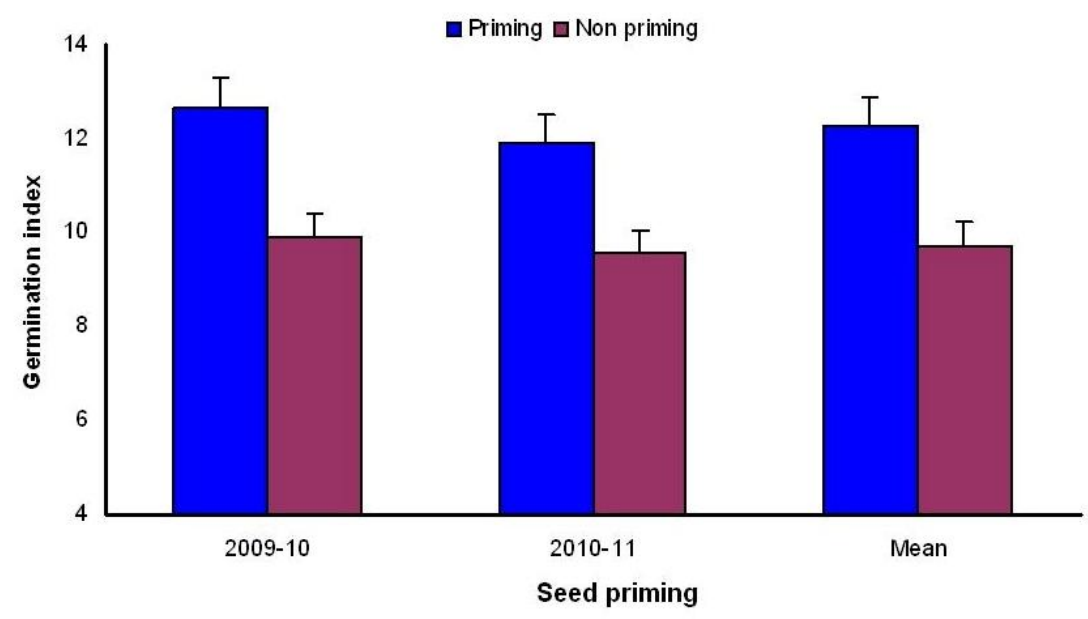

Fig. 3. Effect of priming on the germination index of maize seed in 2009-10 and 2010-11 (Vertical bars represent standard error of means).

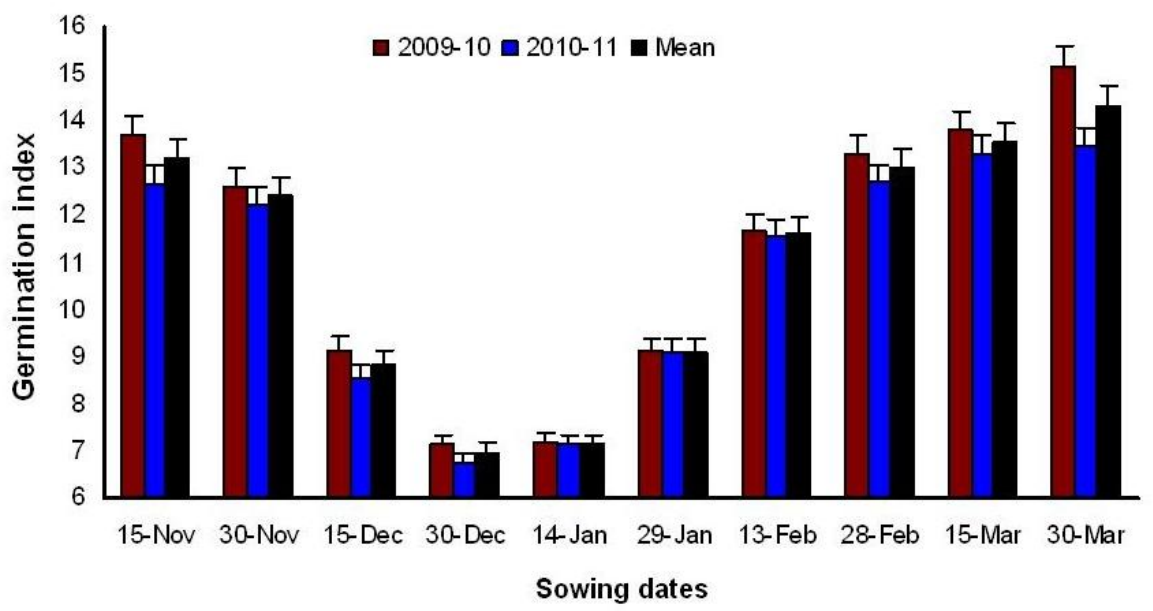

Fig. 4. Effect of sowing dates on the germination index of maize seeds in 2009-10 and 2010-11 (Vertical bars represent standard error of means). 


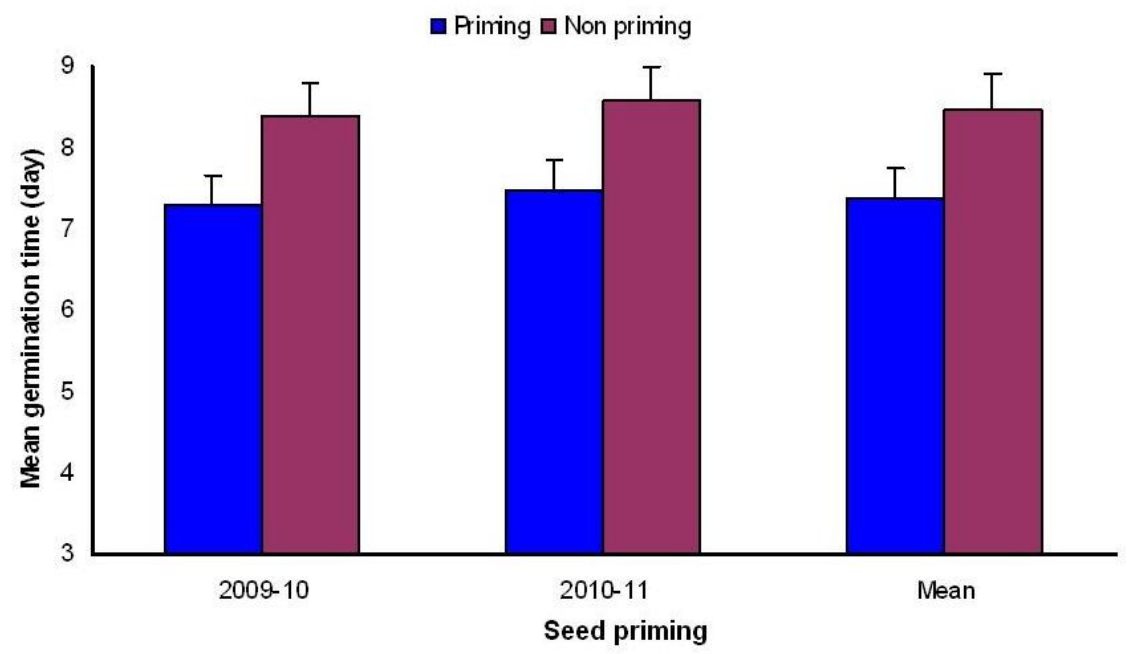

Fig. 5. Effect of priming on the mean germination time of maize seed in 2009-10 and 2010-11 (Vertical bars represent standard error of means).

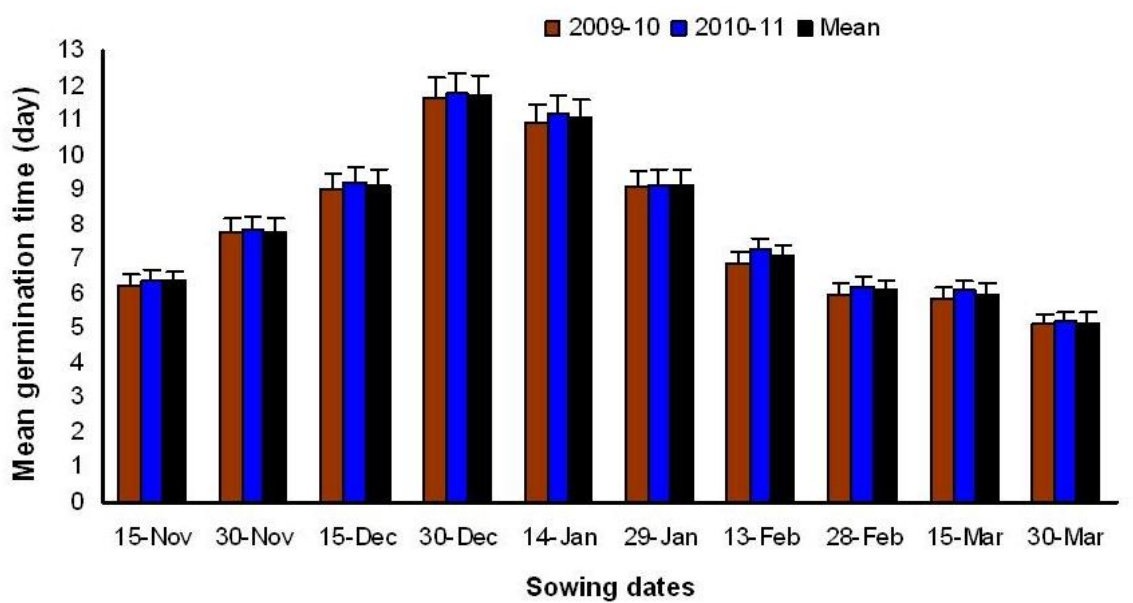

Fig. 6. Effect of sowing dates on the mean germination time of maize seed in 2009-10 and 2010-11 (Vertical bars represent standard error of means). 


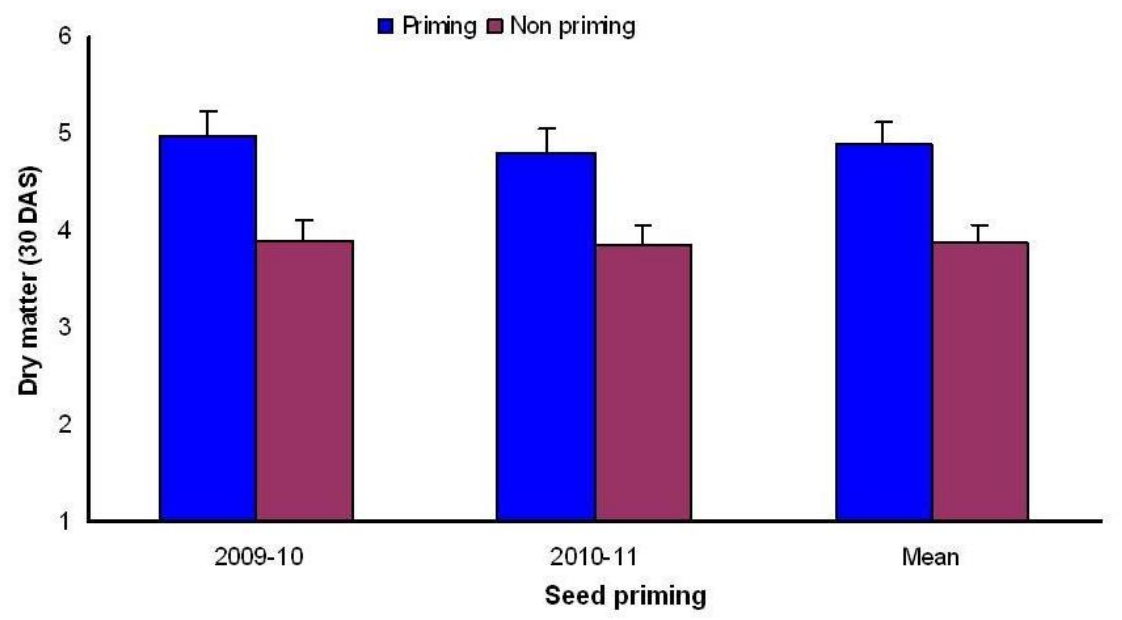

Fig. 7. Effect of priming on the dry matter of maize seedling at $30 \mathrm{DAS}$ in 2009-10 and 2010-11 (Vertical bars represent standard error of means).

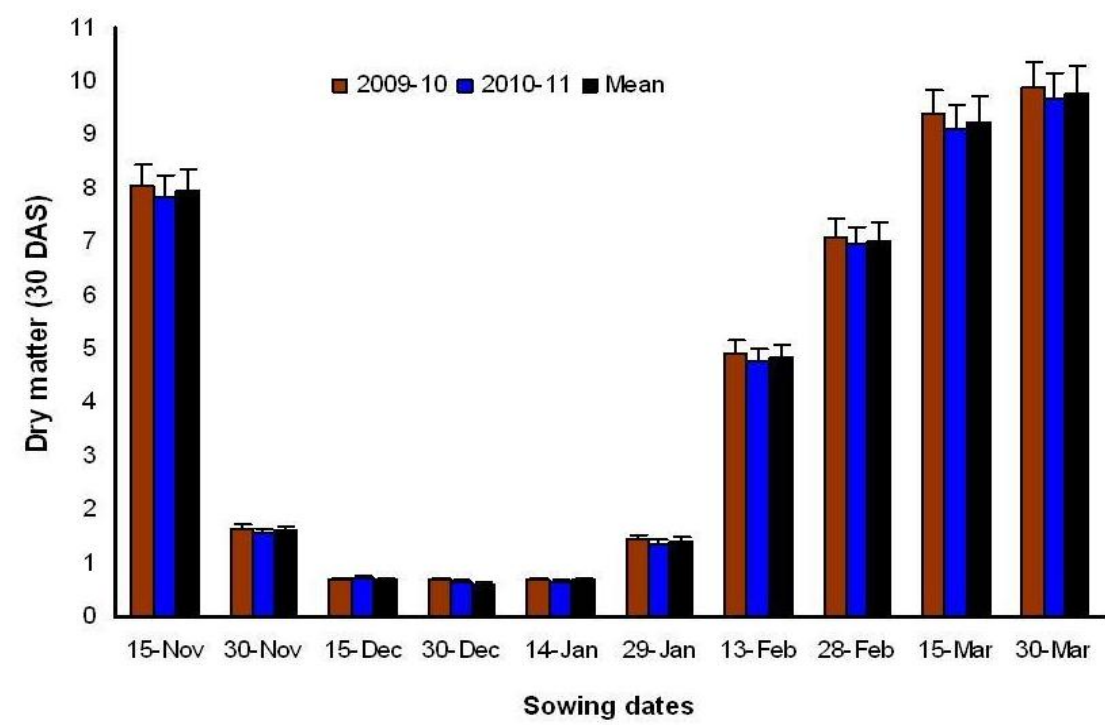

Fig. 8. Effect of sowing dates on the dry matter of maize seedling at 30 DAS in 200910 and 2010-11 (Vertical bars represent standard error of means). 


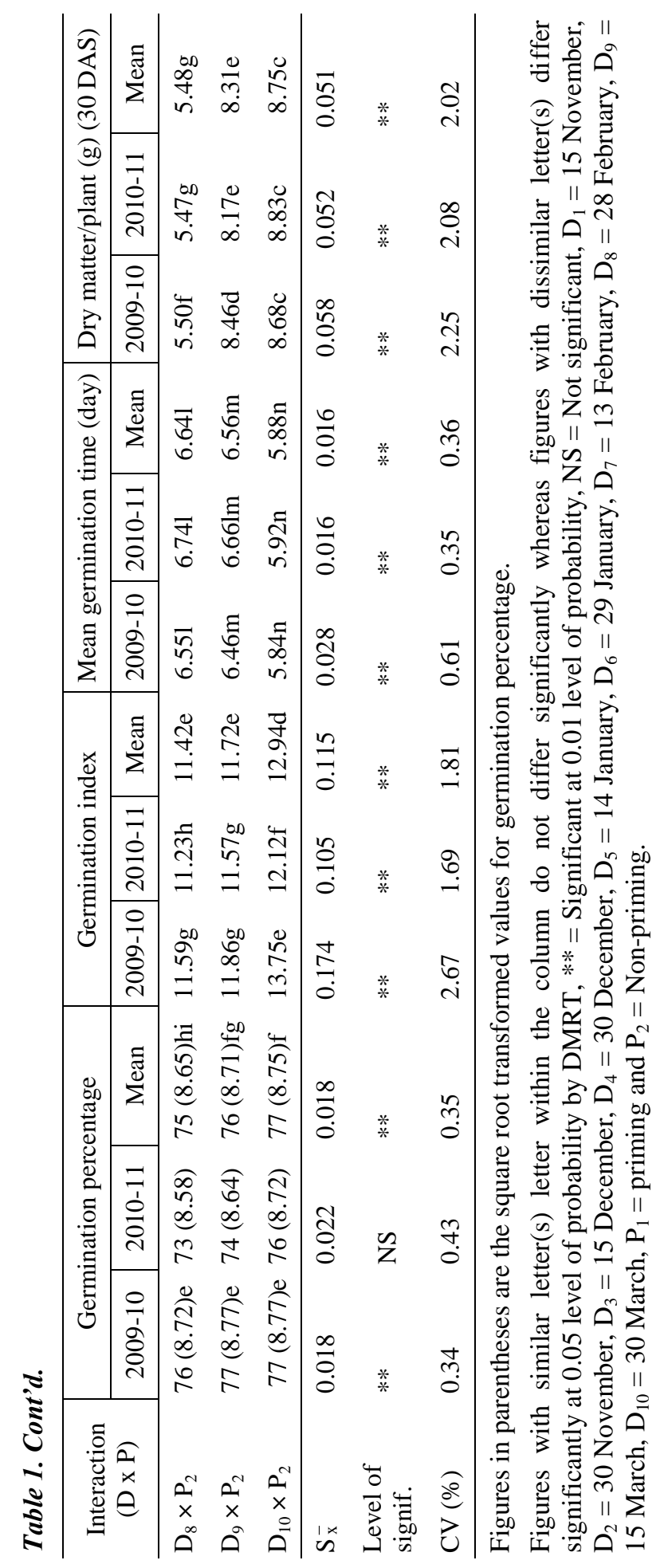




\section{Discussion}

Different factors, such as soil moisture stress, temperature extremities, soil salinity, poor seed bed preparation, weed competition, low seed quality, and extreme disease pressure adversely affect the emergence of maize seed. Seed priming could be used as a viable technology to improve seedling establishment. Rapid and uniform emergence has been achieved by seed priming in some field crops (Murungu et al., 2004).

In this study, emergence performance of maize seeds varied with sowing dates. This difference was mainly related to variation in ambient temperature. Maize seed sown in the month of December and January showed very poor emergence but those sown in March showed the highest emergence. Optimum temperature for maize production is between 25 and $30^{\circ} \mathrm{C}$, if the temperature is lower than that then germination of maize is delayed. Therefore, lower germination was observed in December and January sowing due to lower temperature. This result is at par with the findings of Sikder et al. (2009). Farooq et al. (2008) also found that primed seeds sown at higher temperature showed higher emergence performance and dry matter compared to low temperature. Medany et al. (2007) stated that optimum temperature for maize growing is between 25 and $30^{\circ} \mathrm{C}$. Ambient mean temperature during germination period in this study of both the years were 15 to $16{ }^{\circ} \mathrm{C}, 17$ to $18{ }^{\circ} \mathrm{C}, 19$ to $21{ }^{\circ} \mathrm{C}, 19$ to $25^{\circ} \mathrm{C}$ and 27 to 30 ${ }^{\circ} \mathrm{C}$ when sown in December, January, November, February and March, respectively. Therefore, it was evident from the study that emergence was lower in December and January due to lower temperature than those in November, February, and March.

Higher emergence performance in this study was obtained from sowing of primed seeds at any date compared to non-primed seeds. Seed priming plays a vital role for increasing emergence and stand establishment. So, primed seeds improved seedling emergence for any date of sowing. This result is in line with the findings of Afzal et al. (2008). Primed maize seeds sown in the month of November and February showed higher germination percentage and lower mean germination time compared to hydroprimed seeds sown in December and January. Primed seeds sown on 15 November showed 4\% higher germination and mean germination time reduced by 5.46 days compared to primed seeds sown on 30 December. Similarly February sowing showed higher germination and reduced mean germination time. Though the variation of germination 
percentage was narrower but it took longer period for completion of germination and as a result dry matter of maize seedling at 30 DAS reduced more (Table 1). So, primed seeds sown in December and January could not achieve the required emergence as compared to primed seeds sown on 15 November and February.

In Bangladesh, the optimum sowing time of maize is October to November in rabi season and mid February to March in kharif season (BARI, 2006). In the study, maize seeds sown in December and January showed very poor emergence whereas November and February sowing showed better emergence.

\section{Conclusion}

Primed seeds sown in March showed highest emergence of maize whereas it was very poor when sown in December and January. Primed maize seeds sown in the month of November and February showed higher germination percentage, germination index, dry matter and lower mean germination time compared to primed seeds sown in December and January. So, it may be concluded that primed seeds could be sown in November and February for better production of maize in Bangladesh.

\section{References}

Afzal, I., S.M.A. Basra, M. Shahid, M. Farooq and M. Saleem. 2008. Priming enhances germination of spring maize (Zea mays L.) under cool temperature. Seed Sci. Technol. 36(2): 497-503.

AOSA (Association of Official Seed Analysts).1983. Seed Vigor Testing Handbook. Contribution No. 32 to the handbook on Seed Testing, Pp.30-32.

BARI (Bangladesh Agricultural Research Institute). 2006. Krishi Projukti Hatboi (in Bengali). Bangladesh. Agril. Res. Inst., Gazipur 1701, Bangladesh, P.45.

Basu, S., S.P. Sharma and M. Dadlani. 2005. Effect of hydropriming on field emergence, crop performance and seed yield of maize parental lines during winter and spring-summer season. Seed Res. 33(1): 24-27.

BBS. 2010. Statistical Year Book of Bangladesh. Bangladesh Bureau of Statistics, Ministry of Planning, Government of the Peoples Republic of Bangladesh. Pp.37-49.

Farooq, M., T. Aziz, S.M.A. Basra, M.A. Cheema and H. Rehman. 2008. Chilling tolerance in hybrid maize induced by seed priming with salicylic acid. J. Agron. and Crop Sci. 194(2):161-168. 
Finch-Savage, W.E., K.C. Dent and L.J. Clark. 2004. Soak conditions and temperature following sowing influence the response of maize (Zea mays L.) seeds to on-farm priming (pre-sowing seed soak). Field Crops Res. 90(2/3): 361-374.

Gomez, K.A. and A.A. Gomez. 1984. Statistical Procedures for Agriculture Research. Intl. Rice. Res. Inst., Philippines, Pp.187-411.

Harris, D., A. Joshi, P.A. Khan, P. Gothakar, and P.S. Sodhi. 1999. On-farm seed priming in semi-arid agriculture: Development and evaluation in corn, rice and chickpea in India using participatory methods. Exp. Agric. 35:15-29.

Harris, D., A.K. Pathan, P. Gothkar, A. Joshi, W. Chivasa and P. Nyamudeza. 2001. Onfarm seed priming using participatory methods to revive and refine a key technology. Agril. Systems. 69:151-164.

Hossain, A. and M. Shahjahan. 2007. Grain quality evaluation of the major varieties or cultivar of maize. Research report of the year 2006-07. Post harvest Technology Division, BARI, Joydebpur, Gazipur, Pp. 1-6.

McDonald, M.B. 2000. Seed Technology and Its Biological Basis. Sheffield Academic Press Ltd., Sheffield, UK, Pp. 287-325.

Medany, M.A., A.K. Hegazy, H.F. Kabiel and M.M. Maez. 2007. Prediction of seed germination and seedling growth of crop plants as affected by root zone temperature. World J. Agril. Sci.3 (6): 714-720.

Murungu, F.S., C. Chiduza, P. Nyamugafata, L.J. Clark, W.R. Whalley and W.E. FinchSavage. 2004. Effects of on-farm seed priming on consecutive daily sowing occasions on the emergence and growth of maize in semi-arid Zimbabwe. Field Crops Res. 89(1): 49-57.

Nagar, R.P, M. Dadlani and S.P. Sharma. 1998. Effect of hydropriming on field emergence and crop growth of maize genotypes. Seed Res. 26(1): 1-5.

Rashid, A., D. Harris, P.A. Hollington and R.A. Khattak. 2002. On-farm seed priming: a key technology for improving the livelihood of resource poor farmers on saline lands. Centre for Arid Zone studies, University of Wales, UK, Pp.37-39.

Scott, S. L., R.A. Jones and W.A. Williams. 1984. Review of data analysis methods for seed germination. Crop Sci. 24:1192-1198.

Shivankar, R.S., D.B. Deore and N.G. Zode. 2003. Effect of pre-sowing seed treatment on establishment and seed yield of sunflower. J. Oilseed Res. 20: 299-300.

Sikder, S., M.A. Hasan and M.S. Hossain. 2009. Germination characteristics and mobilization of seed reserves in maize varieties as influenced by temperature regimes. J. Agric. Rural Dev. 7(1\&2): 51-56. 
Singh, B.G. 1995. Effect of hydration dehydration seed treatments on vigour and yield of sunflower. Indian J. Plant. Physiol. 38: 66-68.

Townend, J., P.W. Mtakwa, C.E. Mullins and I.P. Simmonds. 1996. Soil physical factors limiting establishment of sorghum and cowpea in two contrasting soil types in the semi-arid tropics. Soil Till. Res. 40: 89-106. 